\title{
Needs and expectations for an AR program for asthma education for school-age children in South Korea: The perspectives of children, parents, and teachers
}

\author{
Yunsoo Kim ${ }^{1}$, Hyojin $\mathrm{Ju}^{2}$ \\ ${ }^{1}$ Assistant Professor, Department of Nursing, Catholic Kwandong University, Gangneung · Senior Researcher, The Convergence Institute of Healthcare and \\ Medical Science, Incheon; ${ }^{2}$ Professor, Department of Medical Science, Catholic Kwandong University, Gangneung · Senior Researcher, The Convergence Institute \\ of Healthcare and Medical Science, Incheon, Korea
}

Purpose: This study examined the needs for asthma education programs as perceived by school-age children, parents, and teachers and investigated parents' and teachers' expectations for incorporating augmented reality (AR) in asthma education. Methods: This descriptive, cross-sectional study included 339 participants: 125 school-age children, 132 parents, and 82 teachers. Data were collected from children, parents, and teachers on the need for asthma education, the requirements for asthma education, and the expectations of parents and teachers for incorporating AR in asthma education. Data were analyzed using descriptive statistics, the t-test, analysis of variance, and the Scheffé test. Results: Asthmatic children and their peers, parents, and teachers all felt there was a significant need for education about asthma, with education on how to deal with an asthma attack being needed the most. The incorporation of AR programs in asthma education was viewed positively by both parents and teachers. Conclusion: An AR children's asthma education program should be developed in which children with asthma and their peers, parents, and teachers can participate together. Furthermore, it is expected that children with asthma will independently undertake more effective disease management after attending an AR asthma education program.

Key words: School; Children; Asthma; Education; Augmented reality

\author{
Corresponding author \\ Yunsoo Kim \\ Department of Nursing, Catholic \\ Kwandong University, 24 Beomil-ro, 579 \\ beon-gil, Gangneung 25601, Korea \\ TEL: +82-33-649-7614 \\ FAX: $+82-33-649-7610$ \\ E-MAIL: agneskim4320@gmail.com \\ This study was presented in 2021 as a poster \\ at the 13th International Nursing \\ Conference of the Korean Society of Nursing \\ Science.
}

Received Aug 3, 2021

Revised Sep 2, 2021

Accepted Sep 23, 2021

\section{INTRODUCTION}

Asthma is one of the most common chronic allergic diseases among children and is characterized by airway changes and various airway symptoms. If childhood asthma is not adequately treated and continuously managed, there is a risk of irreversible airway deformation during the transition into adulthood [1]. Asthmatic children all over the world experience symptoms on a daily basis that can severely affect their everyday lives. In South Korea, children made up the highest proportion of asthma treatment patients by age group per 100,000 population in 2018 [2].

If a child has a medical condition, his or her parent or out-of-state guardian is primarily responsible for managing the condition until pre-school age [3]. However, school-age children spend almost one-third of their day at school, and asthma management largely depends on the child's self-management or teachers. Therefore, school life plays a crucial role in childhood asthma management [4].

Children with asthma often have a limited ability to participate in physical activities at school [5,6]. As a result, children with asthma are at risk of obesity and may also experience feelings of alienation and bullying due to the perception that they are different from others stemming from their inability to perform physical activities with their peers [7]. Parents of children with asthma and other allergic diseases may also feel anxious that their children do not correctly recognize exacerbation symptoms. In addition, there have been instances in which parents have chosen not to send their child to school due to increased anxiety that the school system will not prop- 
erly care for their child if the child's asthma symptoms are severe [5]. Furthermore, teachers often rely on children with asthma to manage their own symptoms independently due to the large number of students they have to supervise [8].

The age of school-age children ranges from 6 to 12 years old, and during this time in children's lives, they learn to think logically about specific events and actions and develop the ability to think actively. Therefore, school-age children learn to undertake effective disease management only once they develop independent agency rather than depending on and being controlled by their parents [9]. According to Bandura's social cognitive theory [10], learning in a social context is achieved through interaction between the environment, individual variables, and behavior. An essential strategy for asthma management among school-age children is to promote self-efficacy and motivation related to their asthma management. Asthma self-management can reduce morbidity and the use of healthcare systems among children and adolescents with asthma. Therefore, an educational program that addresses the educational needs of children with asthma, as well as their peers, parents, and teachers, would lead to an increase in the self-management abilities of children with asthma.

Augmented reality (AR) enables interactive experiences in which objects in the real world are enhanced by computergenerated perceptual experiences [11]. AR enables virtual and real worlds to coexist and interact in real-time, facilitating user engagement and active participation in learning. AR programs have been shown to provide exciting and fun educational experiences while engaging students [12]. AR programs have also been found to be safe and to help children determine their future courses of action related to asthma prevention and disease management [13]. Therefore, if a children's asthma education program is developed that incorporates an AR program, it is expected that children would be able to independently undertake effective disease management by learning how to practice allergen avoidance to prevent asthma attacks and use an inhaler during an asthma attack. In addition, the participation of parents, teachers, and peers in such an AR program could also help improve symptoms in children with asthma.

Previous studies on the asthma education needs of schoolage children have mainly been conducted on parents and families, and teachers rather than on children. Few studies have surveyed the needs of school-age children and their peers, teachers, and parents. In addition, no studies have been conducted on the expectations of teachers and parents concerning the implementation of an AR program in asthma education.

Therefore, in this study, primary data were obtained for the development of asthma education programs for school-age children that incorporate AR by identifying the educational needs of school-age children, parents, and teachers and examining the expectations of parents and teachers for an AR education program.

\section{METHODS}

Ethics statement: This study was approved by the institutional review board of Catholic Kwandong University (No. CKU-19-01-0109). Informed consent was obtained from the participants.

\section{Study Design}

This cross-sectional descriptive research study investigated the need for education related to asthma in school-age children and examined parents' and teachers' expectations for incorporating AR programs into asthma education for schoolage children.

\section{Study Population}

The subjects of this study were 125 school-age children, 132 parents, and 82 teachers, comprising a total of 339 participants. The sample size of the subjects was determined based on a significance level of .05 , a power of .95 , and a medium effect size of .25 for each of the 3 groups using the F-test and G-Power version 3.1.9 [14], and the minimum required sample size was calculated to be 252 people. In general, the estimated dropout rate in questionnaire-based research is estimated to be $20 \%$, and considering that the recovery rate of online surveys was found to be around $30 \%$, the dropout rate was set to $30 \%$. A total of 353 questionnaires were distributed and 339 were collected, all of which were used for analysis. The inclusion and exclusion criteria used for selecting subjects in this study were as follows. Inclusion criteria for children were understanding the purpose and methods of this study, having a parent or guardian who consented to participate in the study, and (for children aged 7 to 12) being able to understand, respond to, and engage with the questionnaire. While school age is generally considered 6 to 12 years old, children in elementary school were considered school-age children in this study; therefore, children aged 7 to 12 years old were selected as subjects. The selection criteria for parents and teachers were understanding the purpose and methods of this study, consenting to participate in the study, and being able to understand, respond to, and engage with the content of the questionnaire. The exclusion criterion was a lack of consent to participate in the study for children, parents or guardians, and teachers. 


\section{Measurements}

\section{1) General characteristics of the study population}

\section{(1) Children}

The baseline characteristics of school-age children used in this study were sex, age, grade, height, weight, the presence of an allergic disease, and the type of allergic disease. Furthermore, the children were classified into 2 categories according to the presence of asthma or an allergic condition, with those who answered "yes" being considered children with asthma and those who answered "no" being considered their peers.

\section{(2) Parents}

The general characteristics of parents that were collected were sex, age, and allergic disease status, in addition to the child's sex, age, grade, allergic disease status, allergic disease type, and history of allergic shock.

\section{(3) Teachers}

The general characteristics of teachers that were used in this study were sex, age, school subject, teaching experience, allergic disease status, history of educational experiences related to students with allergic diseases, and history of treating asthma and allergic shock in students with asthma.

\section{2) Needs for asthma education}

A visual analog scale out of 10 was used to measure the asthma education needs of children with asthma as well as their peers, parents, and teachers. The scale measured the degree to which children, parents, and teachers believed each group required asthma education.

\section{3) Needs for asthma education content}

The needs for asthma education content were measured using a self-report questionnaire created by the researcher based on previous studies [4,6,15-18]. The items for which children, parents, and teachers required education related to asthma in school-age children in previous studies as identified in a literature review were as follows: the causes of asthma, asthma treatment, asthma medications, things that help or harm people with asthma, exercise during asthma, preventive measures, what to do in case of an asthma attack, what to do in special situations, how to improve the environment for children with asthma. The researchers developed the questionnaire to assess needs for asthma education content based on the selected items. The validity of the developed questionnaire was tested by experts including two child nursing professors and two nurses with more than 10 years of experience in pediatrics. Following validation by experts, the content validity index was found to be .83 . The asthma education needs ques- tionnaire was pilot tested with 10 parents and teachers. The final questionnaire consisted of three domains: asthma primary (asthma causes and treatment goals, what harms or helps when children have asthma), asthma medication (name of asthma medication, the efficacy of each type of asthma medication, side effects of asthma medication, type and usage of inhaled asthma medication), and coping with asthma and medical expectations (physical activity with asthma, preventive measures, what to do in case of an asthma attack, what to do in particular situations, how to improve the environment for children with asthma).

The needs for asthma education content targeted to schoolage children, parents, and teachers were examined. The children's questionnaire consisted of child-friendly sentences (e.g., "I am curious as to why I get asthma"). The questionnaire for children, parents, and teachers was answered using a 14 -item, 5-point Likert scale, with 1 point indicating "not very important" and 5 points indicating "very important."

\section{4) Expectations for the incorporation of $A R$ in asthma education}

A tool developed by Park et al. [19] was used to measure parents' and teachers' expectations for the incorporation of AR in asthma education. The tool consists of 6 items in the positive expectation domain and 6 items in the negative concern domain and is answered using a 5-point Likert scale, with 1 point indicating "strongly disagree" and 5 points indicating "strongly agree." A higher score indicated a higher degree of positive expectations and negative concerns. The tool's reliability at the time of its development was indicated by a Cronbach's $\alpha$ of .76 for positive expectations and .78 for negative concerns. In this study, the reliability was indicated by a Cronbach's $\alpha$ of .82 for positive expectations and .81 for negative concerns.

\section{Ethical Considerations and Data Collection}

Data collection in this study was conducted from September 11, 2019, to February 26, 2020, and was carried out after receiving approval from the institutional research ethics review board (CKU-19-01-0109). This study was conducted using a Google questionnaire targeting elementary school students, parents, and elementary school teachers in 5 cities and provinces (Seoul, Gyeonggi, Gangwon, Chungnam, and Gyeongnam). The researcher obtained permission from the principals of each school after explaining the purpose and methods of the study. Participants were asked to provide written informed consent to participate in the survey. The Google questionnaire included an explanation of the purpose of the research, a statement guaranteeing the anonymity and confidentiality of participants and that the data would only be used for academic purposes. In addition, participants had the option to with- 
draw from participation at any point and face no consequences. Parents' provided permission for their children to participate in the study, and the URL to the questionnaire was distributed after the children also provided their consent to participate. After consenting to participate in the study, the URL of the questionnaire was distributed to parents and teachers. The questionnaire took 10 to 15 minutes to complete. The researcher or a teacher accompanied the children as they completed the questionnaire and explained the content, allowing the children to respond. The study subjects were provided with a gift in exchange for their participation.

\section{Statistical Analysis}

The collected data was analyzed using SPSS/WIN Version 22.0 (IBM Corp., Armonk, NY, USA). The general characteristics of subjects were analyzed using descriptive statistics for frequency, percentage, mean, and standard deviation. Differences in the asthma education needs for each group and the requirements of asthma education content between school-age children with asthma and their peers, parents, and teachers were analyzed using analysis of variance (ANOVA), and post hoc analysis was conducted using the Scheffé test. In addition, the asthma education needs of children with asthma and their peers, parents, and teachers were analyzed by domain using ANOVA followed by the Scheffé test. Differences between the parents' and teachers' expectations for incorporating AR into asthma education were analyzed using the t-test.

\section{RESULTS}

\section{General Characteristics}

Table 1 shows the general characteristics of participants.

\section{1) Children}

The average age of the children was 10.4 years old, and $45.6 \%$ of the children were male, while $54.4 \%$ were female. The most common grade levels were fourth and fifth grade (20.8\%). The average height was $139.0 \mathrm{~cm}$, the average weight was $36.1 \mathrm{~kg}$, and the average body mass index was 18.4 $\mathrm{kg} / \mathrm{m}^{2}$. A total of $31.2 \%$ of the children had allergic diseases, while $68.8 \%$ did not. Allergic diseases in children were investigated as duplicate responses. Of the 39 children with allergies, $48.7 \%$ had asthma, $38.5 \%$ had allergic rhinitis, and $41.0 \%$ had atopic dermatitis.

\section{2) Parents}

The average age of the parents was 40.8 years old. In total, $78.8 \%$ of parents were female, and $21.2 \%$ were male. A total of
Table 1. General Characteristics of Children, Parents, and Teachers $(N=339)$

\begin{tabular}{|c|c|c|}
\hline Characteristics & Categories & $\begin{array}{l}\mathrm{n}(\%) \text { or } \\
\mathrm{M} \pm \mathrm{SD}\end{array}$ \\
\hline \multicolumn{3}{|l|}{ Children (n=125) } \\
\hline Age (year) & & $10.4 \pm 1.7$ \\
\hline Sex & $\begin{array}{l}\text { Male } \\
\text { Female }\end{array}$ & $\begin{array}{l}57(45.6) \\
68(54.4)\end{array}$ \\
\hline Grade & $\begin{array}{l}1 \text { st } \\
\text { 2nd } \\
\text { 3rd } \\
4 \text { th } \\
5 \text { th } \\
6 \text { th }\end{array}$ & $\begin{array}{l}21(16.8) \\
21(16.8) \\
15(12.0) \\
26(20.8) \\
26(20.8) \\
16(12.8)\end{array}$ \\
\hline Height & & $139.0 \pm 13.1$ \\
\hline Weight & & $36.1 \pm 11.7$ \\
\hline $\operatorname{BMI}\left(\mathrm{kg} / \mathrm{m}^{2}\right)$ & & $18.4 \pm 4.8$ \\
\hline Allergic disease & $\begin{array}{l}\text { Yes } \\
\text { No }\end{array}$ & $\begin{array}{l}39(31.2) \\
86(68.8)\end{array}$ \\
\hline $\begin{array}{l}\text { Type of allergic disease* } \\
(\mathrm{n}=39)\end{array}$ & $\begin{array}{l}\text { Asthma } \\
\text { Allergic rhinitis } \\
\text { Atopic dermatitis }\end{array}$ & $\begin{array}{l}19(48.7) \\
15(38.5) \\
16(41.0)\end{array}$ \\
\hline \multicolumn{3}{|l|}{ Parents (n=132) } \\
\hline Age (year) & & $40.8 \pm 4.1$ \\
\hline Sex & $\begin{array}{l}\text { Male } \\
\text { Female }\end{array}$ & $\begin{array}{c}28(21.2) \\
104(78.8)\end{array}$ \\
\hline Father's allergic disease & $\begin{array}{l}\text { Yes } \\
\text { No }\end{array}$ & $\begin{array}{l}37(28.0) \\
95(72.0)\end{array}$ \\
\hline Mother's allergic disease & $\begin{array}{l}\text { Yes } \\
\text { No }\end{array}$ & $\begin{array}{l}35(26.5) \\
97(73.5)\end{array}$ \\
\hline Children's age (year) & & $10.5 \pm 1.7$ \\
\hline Children's sex & $\begin{array}{l}\text { Male } \\
\text { Female }\end{array}$ & $\begin{array}{l}67(50.8) \\
65(49.2)\end{array}$ \\
\hline Children's allergic disease & $\begin{array}{l}\text { Yes } \\
\text { No }\end{array}$ & $\begin{array}{l}52(39.4) \\
80(60.6)\end{array}$ \\
\hline $\begin{array}{l}\text { Type of children's allergic } \\
\text { disease }^{*}(n=52)\end{array}$ & $\begin{array}{l}\text { Asthma } \\
\text { Allergic rhinitis } \\
\text { Atopic dermatitis } \\
\text { Food allergy } \\
\text { Etc. }\end{array}$ & $\begin{array}{c}19(36.5) \\
36(69.2) \\
16(30.8) \\
6(11.5) \\
2(3.8)\end{array}$ \\
\hline $\begin{array}{l}\text { Children's allergic shock } \\
(\mathrm{n}=52)\end{array}$ & $\begin{array}{l}\text { Yes } \\
\text { No }\end{array}$ & $\begin{array}{c}2(1.5) \\
50(37.9)\end{array}$ \\
\hline \multicolumn{3}{|l|}{ Teachers $(\mathrm{n}=82)$} \\
\hline Age (year) & & $44.1 \pm 7.9$ \\
\hline Sex & $\begin{array}{l}\text { Male } \\
\text { Female }\end{array}$ & $\begin{array}{c}4(4.9) \\
78(95.1)\end{array}$ \\
\hline $\begin{array}{l}\text { Teaching experience } \\
\text { (month) }\end{array}$ & & $222.7 \pm 7.9$ \\
\hline Subjects taught & $\begin{array}{l}\text { General teacher } \\
\text { Health teacher }\end{array}$ & $\begin{array}{c}76(92.7) \\
6(7.3)\end{array}$ \\
\hline Students' allergic disease & $\begin{array}{l}\text { Yes } \\
\text { No }\end{array}$ & $\begin{array}{l}69(84.1) \\
13(15.9)\end{array}$ \\
\hline Students' allergic shock & $\begin{array}{l}\text { Yes } \\
\text { No }\end{array}$ & $\begin{array}{l}18(22.0) \\
64(78.0)\end{array}$ \\
\hline
\end{tabular}

*Multiple response item; BMI, body mass index. 
$28.0 \%$ of fathers and $26.5 \%$ of mothers had an allergic disease. The average age of parents' children was 10.5 years old, and $50.8 \%$ and $49.2 \%$ of their children were male and female, respectively. Furthermore, $39.4 \%$ of the parents reported having children with an allergic disease, $36.5 \%$ of whom had asthma, $69.2 \%$ of whom had allergic rhinitis, $30.8 \%$ of whom had atopic dermatitis, and $11.5 \%$ of whom had a food allergy. In total, $1.5 \%$ of children with allergic diseases had a history of allergic shock.

\section{3) Teachers}

The average age of the teachers was 44.1 years old, and $95.1 \%$ of the teachers were women. Their average degree of educational experience was 222.7 months, and 92.7\% were general teachers while $7.3 \%$ were health teachers. Among their students, $84.1 \%$ had an allergy, and $22.0 \%$ of the students had experienced an allergic shock.

\section{Needs for Asthma Education}

Table 2 shows the need for asthma education among schoolage children with asthma and their peers, parents, and teachers. The highest need for asthma education for children with asthma was reported by teachers, with an average score of 8.82, and there was a significant difference among the groups $(\mathrm{F}=6.47, p<.001)$. The highest need for asthma education for children's peers was reported by parents, with an average score of 8.39 points, and a significant difference was observed among the groups $(\mathrm{F}=3.08, p=.028)$. Parents also reported the highest need for asthma education, with an average score of 8.43 points, and significant differences were present among the groups $(\mathrm{F}=9.00, p<.001)$. Lastly, parents expressed the highest need for asthma education, with an average score of 8.58 points, and a significant difference was also observed among the groups $(\mathrm{F}=7.30, p<.001)$.

\section{Needs for School-age Asthma Education Program Content}

Table 3 and Figure 1 show the requirements for an asthma education program for school-age children according to the subjects of this study. The parents averaged 4.38 points for the overall score of all items, while teachers averaged 4.26 points, asthma children averaged 3.66 points, and peers averaged 3.46 points, with significant differences between the groups $(\mathrm{F}=40.02, p<.001)$. The differences in the content requirements for an asthma education program according to children, parents, and teachers were statistically significant between groups for all items. The score for "what to do if a child has an asthma attack" was highest in all four groups, with an average score of 4.78 points among teachers, 4.63 points among parents, 4.05 points among children with asthma, and 4.03 points among peers. "Appropriate exercises and an appropriate amount of exercise," "what can harm children who have asthma symptoms," "what can help children who have asthma symptoms," and "how to prevent asthma symptoms" were the other items with high scores in the four groups.

Parents reported the highest need for education related to the asthma primary domain, with an average of 4.40 points, and there was a significant difference among the groups $(\mathrm{F}=$ 21.71, $p<.001$ ). Similarly, parents expressed the highest need for education related to asthma medication, with an average score of 4.20 points, and a significant difference was also observed among the groups $(\mathrm{F}=19.09, p<.001)$. Finally, teachers reported the highest need for education related to coping with asthma and medical expectations, and there was a significant difference among the groups $(\mathrm{F}=85.04, p<.001)$.

Table 2. Needs for Asthma Education Perceived by Children, Parents, and Teachers $(N=339)$

\begin{tabular}{|c|c|c|c|c|c|c|}
\hline \multirow[t]{2}{*}{ Variables } & $\begin{array}{l}\text { Children with } \\
\text { asthma } \\
(\mathrm{n}=19)\end{array}$ & $\begin{array}{c}\text { Peers of children } \\
\text { with asthma }{ }^{b} \\
(n=106)\end{array}$ & $\begin{array}{l}\text { Parents } \\
(\mathrm{n}=132)\end{array}$ & $\begin{array}{l}\text { Teachers }^{\mathrm{d}} \\
(\mathrm{n}=82)\end{array}$ & $\mathrm{F}$ & $p$ \\
\hline & $\mathrm{M} \pm \mathrm{SD}$ & $\mathrm{M} \pm \mathrm{SD}$ & $\mathrm{M} \pm \mathrm{SD}$ & $\mathrm{M} \pm \mathrm{SD}$ & & \\
\hline $\begin{array}{l}\text { Need for asthma education for } \\
\text { children with asthma }\end{array}$ & $7.95 \pm 2.42$ & $7.44 \pm 2.68$ & $8.41 \pm 2.16$ & $8.82 \pm 1.71$ & 6.47 & $\begin{array}{l}<.001 \\
\mathrm{~d}>\mathrm{b}^{*}\end{array}$ \\
\hline $\begin{array}{l}\text { Need for asthma education for } \\
\text { peers of children with asthma }\end{array}$ & $7.53 \pm 2.80$ & $7.54 \pm 2.59$ & $8.39 \pm 2.09$ & $8.12 \pm 2.07$ & 3.08 & .028 \\
\hline $\begin{array}{l}\text { Need for asthma education for } \\
\text { parents }\end{array}$ & $8.32 \pm 2.11$ & $7.04 \pm 2.74$ & $8.43 \pm 1.96$ & $8.41 \pm 2.07$ & 9.00 & $\begin{array}{c}<.001 \\
\mathrm{c}, \mathrm{d}>\mathrm{b}^{*}\end{array}$ \\
\hline $\begin{array}{l}\text { Need for asthma education for } \\
\text { teachers }\end{array}$ & $8.26 \pm 2.23$ & $7.33 \pm 2.69$ & $8.58 \pm 2.03$ & $8.54 \pm 1.78$ & 7.30 & $<.001$ \\
\hline
\end{tabular}

*Scheffé test, $p<.050$. 
Table 3. Asthma Education Needs Perceived by Children, Peers, Parents, and Teachers $(N=339)$

\begin{tabular}{|c|c|c|c|c|c|c|c|}
\hline \multirow[t]{2}{*}{ Variables } & \multirow[t]{2}{*}{ Categories } & $\begin{array}{l}\text { Children } \\
\text { with asthma } \\
\quad(\mathrm{n}=19)\end{array}$ & $\begin{array}{l}\text { Peers }^{\mathrm{b}} \\
(\mathrm{n}=106)\end{array}$ & $\begin{array}{l}\text { Parents }^{c} \\
(\mathrm{n}=132)\end{array}$ & $\begin{array}{l}\text { Teachers }^{\mathrm{d}} \\
(\mathrm{n}=82)\end{array}$ & \multirow[t]{2}{*}{$\mathrm{F}$} & \multirow[t]{2}{*}{$p$} \\
\hline & & $\mathrm{M} \pm \mathrm{SD}$ & $\mathrm{M} \pm \mathrm{SD}$ & $\mathrm{M} \pm \mathrm{SD}$ & $\mathrm{M} \pm \mathrm{SD}$ & & \\
\hline \multirow[t]{6}{*}{$\begin{array}{l}\text { Asthma } \\
\text { primary }\end{array}$} & 1. Causes of asthma & $3.74 \pm 1.28$ & $3.66 \pm 1.15$ & $4.42 \pm 0.73$ & $4.27 \pm 0.90$ & 14.17 & $\begin{array}{c}<.001 \\
\mathrm{c}>\mathrm{d}^{*}, \mathrm{a}>\mathrm{b}^{*}\end{array}$ \\
\hline & 2. Factors affecting asthma & $3.89 \pm 0.99$ & $3.61 \pm 1.13$ & $4.33 \pm 0.77$ & $4.22 \pm 0.90$ & 12.56 & $\begin{array}{c}<.001 \\
\mathrm{c}, \mathrm{d}>\mathrm{b}^{*}\end{array}$ \\
\hline & 3. Goals of asthma treatment & $3.68 \pm 1.00$ & $3.50 \pm 1.21$ & $4.23 \pm 0.89$ & $3.91 \pm 1.06$ & 10.00 & $\begin{array}{l}<.001 \\
\mathrm{c}>\mathrm{b}^{*}\end{array}$ \\
\hline & $\begin{array}{l}\text { 4. What can help children who have asthma } \\
\text { symptoms }\end{array}$ & $3.89 \pm 1.10$ & $3.68 \pm 1.16$ & $4.48 \pm 0.72$ & $4.45 \pm 0.82$ & 18.23 & $\begin{array}{c}<.001 \\
\mathrm{c}, \mathrm{d}>\mathrm{a}, \mathrm{b}^{*}\end{array}$ \\
\hline & $\begin{array}{l}\text { 5. What can harm children who have asthma } \\
\text { symptoms }\end{array}$ & $4.00 \pm 0.75$ & $3.69 \pm 1.05$ & $4.55 \pm 0.67$ & $4.49 \pm 0.77$ & 24.49 & $\begin{array}{c}<.001 \\
\mathrm{c}, \mathrm{d}>\mathrm{a}, \mathrm{b}^{*}\end{array}$ \\
\hline & Subtotal & $3.84 \pm 0.83$ & $3.63 \pm 0.94$ & $4.40 \pm 0.65$ & $4.26 \pm 0.71$ & 21.71 & $\begin{aligned} &<.001 \\
& c>d^{*}, a>b^{*}\end{aligned}$ \\
\hline \multirow[t]{5}{*}{$\begin{array}{l}\text { Asthma } \\
\text { medication }\end{array}$} & 6. Names of asthma medication & $3.79 \pm 1.03$ & $3.12 \pm 1.25$ & $3.96 \pm 0.96$ & $3.41 \pm 1.11$ & 12.28 & $\begin{array}{c}<.001 \\
\mathrm{a}, \mathrm{c}>\mathrm{b}^{*}\end{array}$ \\
\hline & 7. Effects by type of asthma medication & $3.89 \pm 1.05$ & $3.29 \pm 1.18$ & $4.04 \pm 0.97$ & $3.43 \pm 1.21$ & 10.61 & $\begin{array}{l}<.001 \\
\mathrm{c}>\mathrm{b}^{*}\end{array}$ \\
\hline & 8. Side effects of asthma medications & $3.47 \pm 1.22$ & $3.47 \pm 1.16$ & $4.39 \pm 0.76$ & $4.00 \pm 1.05$ & 18.10 & $\begin{array}{c}<.001 \\
\mathrm{c}>\mathrm{a}, \mathrm{b}^{*}\end{array}$ \\
\hline & $\begin{array}{l}\text { 9. Types and usage of asthma inhalation } \\
\text { drugs }\end{array}$ & $3.47 \pm 1.20$ & $3.31 \pm 1.21$ & $4.42 \pm 0.73$ & $4.27 \pm 0.98$ & 29.00 & $\begin{array}{c}<.001 \\
\mathrm{c}, \mathrm{d}>\mathrm{a}, \mathrm{b}^{*}\end{array}$ \\
\hline & Subtotal & $3.66 \pm 1.00$ & $3.30 \pm 1.06$ & $4.20 \pm 0.74$ & $3.78 \pm 0.95$ & 19.09 & $\begin{array}{c}<.001 \\
\mathrm{c}>\mathrm{d}^{*}, \mathrm{a}, \mathrm{b}^{*}\end{array}$ \\
\hline \multirow{6}{*}{$\begin{array}{l}\text { Asthma } \\
\text { coping and } \\
\text { medical } \\
\text { expectation }\end{array}$} & $\begin{array}{l}\text { 10. Appropriate exercises and an appropriate } \\
\text { amount of exercise }\end{array}$ & $4.00 \pm 0.82$ & $3.55 \pm 1.09$ & $4.48 \pm 0.70$ & $4.52 \pm 0.67$ & 30.27 & $\begin{array}{c}<.001 \\
\mathrm{~d}>\mathrm{a}^{*}, \mathrm{c}>\mathrm{b}^{*}\end{array}$ \\
\hline & 11. How to prevent asthma symptoms & $3.79 \pm 0.98$ & $3.79 \pm 1.22$ & $4.55 \pm 0.68$ & $4.62 \pm 0.70$ & 20.00 & $\begin{aligned} &<.001 \\
& \mathrm{c}, \mathrm{d}>\mathrm{a}, \mathrm{b}^{*}\end{aligned}$ \\
\hline & $\begin{array}{l}\text { 12. What to do if children have an asthma } \\
\text { attack }\end{array}$ & $4.05 \pm 0.85$ & $4.03 \pm 1.05$ & $4.63 \pm 0.66$ & $4.78 \pm 0.5$ & 18.74 & $\begin{array}{c}<.001 \\
\mathrm{c}, \mathrm{d}>\mathrm{a}, \mathrm{b}^{*}\end{array}$ \\
\hline & $\begin{array}{l}\text { 13. How to manage special days for children } \\
\text { with asthma (experience learning on-site, } \\
\text { hospital visits, etc.) }\end{array}$ & $3.74 \pm 1.10$ & $3.72 \pm 1.05$ & $4.44 \pm 0.70$ & $4.74 \pm 0.67$ & 30.47 & $\begin{array}{c}<.001 \\
\mathrm{c}, \mathrm{d}>\mathrm{a}, \mathrm{b}^{*}\end{array}$ \\
\hline & $\begin{array}{l}\text { 14. How to improve the environment for } \\
\text { children with asthma }\end{array}$ & $3.79 \pm 1.03$ & $3.74 \pm 1.10$ & $4.42 \pm 0.77$ & $4.49 \pm 0.65$ & 20.00 & $\begin{array}{c}<.001 \\
\mathrm{c}, \mathrm{d}>\mathrm{a}, \mathrm{b}^{*}\end{array}$ \\
\hline & Subtotal & $3.47 \pm 0.70$ & $3.43 \pm 0.73$ & $4.50 \pm 0.62$ & $4.63 \pm 0.44$ & 85.04 & $\begin{array}{c}<.001 \\
\mathrm{~d}, \mathrm{c}>\mathrm{a}, \mathrm{b}^{*}\end{array}$ \\
\hline Total & & $3.66 \pm 0.78$ & $3.46 \pm 0.82$ & $4.38 \pm 0.62$ & $4.26 \pm 0.58$ & 40.02 & $\begin{array}{c}<.001 \\
\mathrm{c}, \mathrm{d}>\mathrm{a}, \mathrm{b}^{*}\end{array}$ \\
\hline
\end{tabular}

*Scheffé test, $p<.050$.

\section{Expectations for Incorporating AR in Asthma Educa- tion among Parents and Teachers}

Table 4 shows parents' and teachers' expectations for the incorporation of AR in asthma education. There was a statisti- cally significant difference in the scores for positive expectations for AR, with an average score of 3.97 points among teachers and 3.68 points among parents $(t=10.81, p<.001)$. For positive expectations, the items that had a significant difference between parents and teachers were "If a child's area or 
(A)

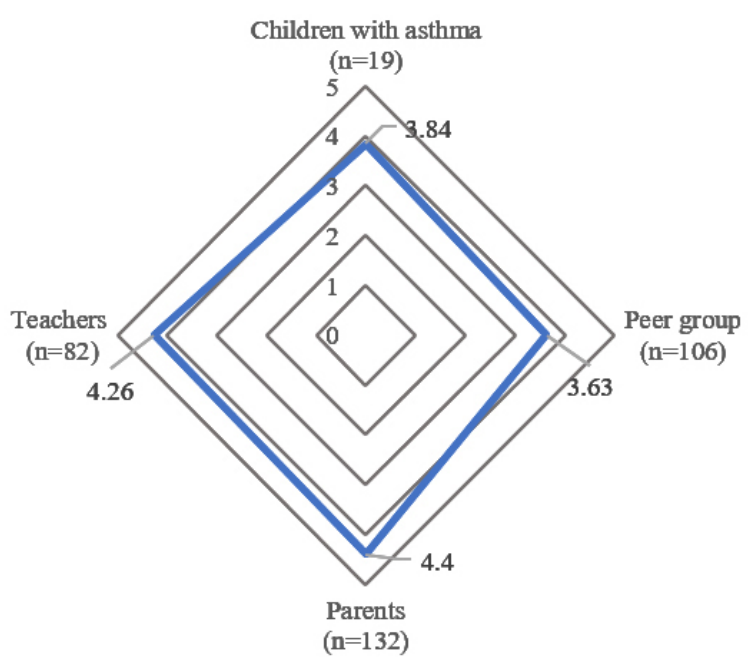

(C)

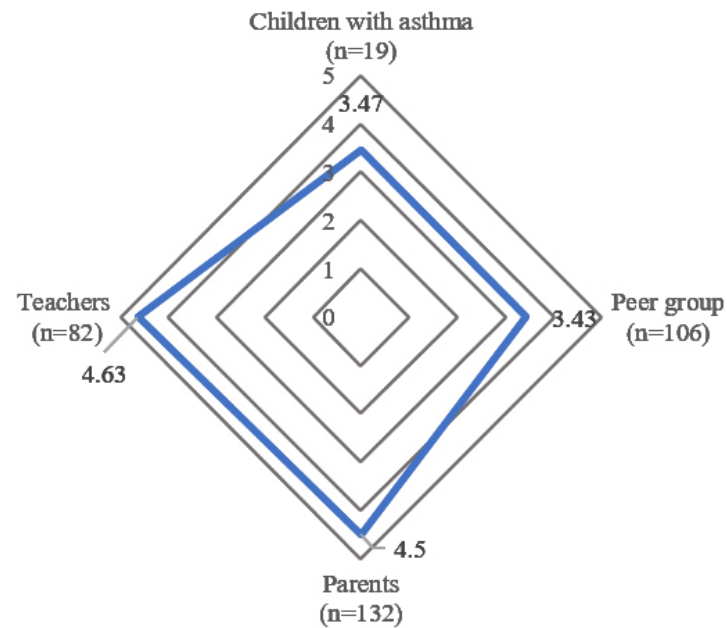

(B)

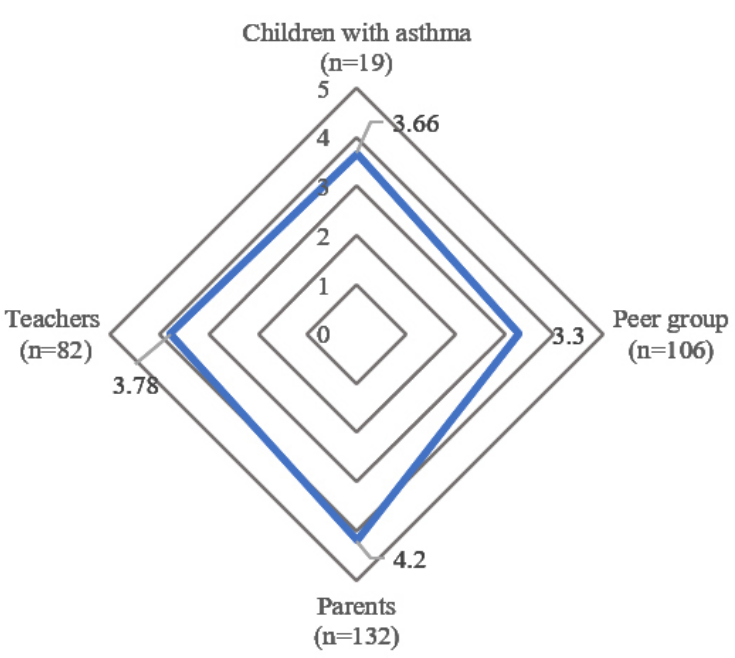

(D)

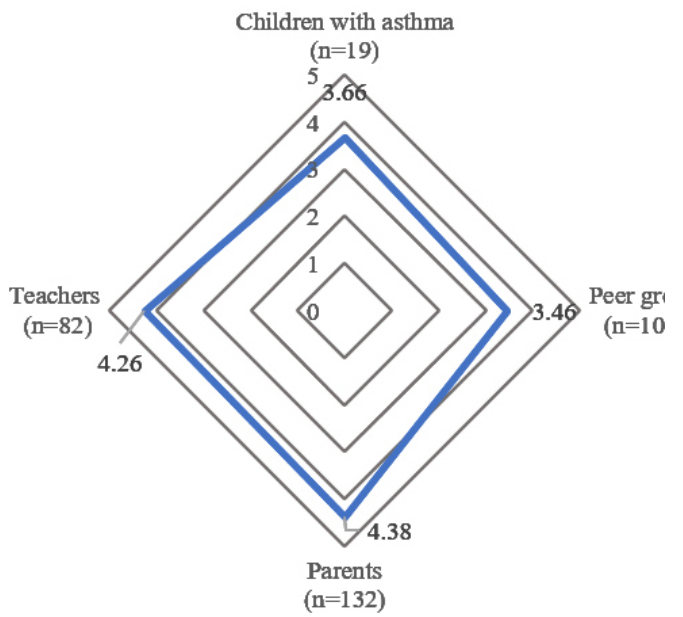

Figure 1. Asthma education needs of children with asthma, peers, parents, and teachers. (A) Asthma primary. (B) Asthma medication. (C) Asthma coping and medical expectation. (D) Total asthma educational needs.

family appears in the AR content, the children will believe they have a friendly relationship with them, which can stimulate interest and motivation" ( $\mathrm{t}=2.57, p=.011$ ), "It seems that children can get an opportunity to broaden their experiences through the medium of AR" ( $\mathrm{t}=2.54, p=.012)$, "I want children to have the opportunity to experience it when they hear the news that a new AR program is out" ( $\mathrm{t}=2.20, p=.029)$, "Although the use of AR content may cause some side effects (e.g., visual fatigue, etc.), I think it is worth using for education" ( $\mathrm{t}=2.44, p=.015)$, "It children show interest in AR content, they will agree to use it as an educational material even if some side effects (e.g., visual fatigue, etc.) are expected" $(\mathrm{t}=2.77, p=.006)$.

For negative concerns about AR, there was a statistically significant difference $(t=9.48, p<.001)$ between parents, who had an average score of 3.13 points, and teachers, who had an average score of 3.02 points. Among the negative concerns about AR, the only item with a statistically significant difference between parents and teachers was "Children are likely to feel burdened by classes that use AR content during class" $(\mathrm{t}=2.33, p=.021)$.

\section{DISCUSSION}

This study was conducted to examine the needs related to asthma education programs for school-age children with asthma and their peers, parents, and teachers and to measure parents' and teachers' expectations for the incorporation of $\mathrm{AR}$ in asthma education.

The need for asthma education according to children with 
Table 4. Expectations for an Augmented Reality Program for Asthma Education by Parents and Teachers $(N=214)$

\begin{tabular}{|c|c|c|c|c|}
\hline \multirow{2}{*}{ Variables } & \multirow{2}{*}{$\begin{array}{c}\text { Parents }(\mathrm{n}=132) \\
\mathrm{M} \pm \mathrm{SD}\end{array}$} & \multirow{2}{*}{$\begin{array}{c}\text { Teachers }(\mathrm{n}=82) \\
\mathrm{M} \pm \mathrm{SD}\end{array}$} & \multirow{2}{*}{$\mathrm{t}$} & \multirow{2}{*}{$p$} \\
\hline & & & & \\
\hline Positive expectations for AR & $3.68 \pm 0.65$ & $3.97 \pm 0.81$ & 10.81 & $<.001$ \\
\hline $\begin{array}{l}\text { 1. If a child's area or family appears in the AR content, the children will } \\
\text { believe they have a friendly relationship with them, which may } \\
\text { stimulate interest and motivation. }\end{array}$ & $3.86 \pm 0.77$ & $4.15 \pm 0.85$ & 2.57 & .011 \\
\hline $\begin{array}{l}\text { 2. Through AR, children seem to be able to taste the freedom they have } \\
\text { never experienced in the virtual world. }\end{array}$ & $3.80 \pm 0.77$ & $4.00 \pm 0.89$ & 1.72 & .087 \\
\hline $\begin{array}{l}\text { 3. It seems that children can get an opportunity to broaden their } \\
\text { experiences through the medium of AR. }\end{array}$ & $3.91 \pm 0.76$ & $4.20 \pm 0.87$ & 2.54 & .012 \\
\hline $\begin{array}{l}\text { 4. I want children to have the opportunity to experience it when they } \\
\text { hear the news that a new AR program is out. }\end{array}$ & $3.85 \pm 0.79$ & $4.11 \pm 0.93$ & 2.20 & .029 \\
\hline $\begin{array}{l}\text { 5. Although the use of AR content may cause some side effects (e.g., } \\
\text { visual fatigue, etc.), I think it is worth using for education. }\end{array}$ & $3.42 \pm 0.86$ & $3.74 \pm 1.04$ & 2.44 & .015 \\
\hline $\begin{array}{l}\text { 6. If children show interest in AR content, they will agree to use it as an } \\
\text { educational material even if some side effects (e.g., visual fatigue, } \\
\text { etc.) are expected. }\end{array}$ & $3.23 \pm 0.98$ & $3.63 \pm 1.09$ & 2.77 & .006 \\
\hline Negative concerns for AR & $3.13 \pm 0.77$ & $3.02 \pm 0.93$ & 9.48 & $<.001$ \\
\hline $\begin{array}{l}\text { 1. I am concerned that the introduction of AR will cause children to } \\
\text { become overly immersed in their favorite content. }\end{array}$ & $3.52 \pm 0.94$ & $3.67 \pm 0.99$ & 1.10 & .274 \\
\hline $\begin{array}{l}\text { 2. When children use AR, interest and interest in flat materials (e.g., } \\
\text { books or video materials) are likely to decrease. }\end{array}$ & $3.34 \pm 0.92$ & $3.56 \pm 1.11$ & 1.57 & .117 \\
\hline $\begin{array}{l}\text { 3. Children are likely to feel burdened by classes that use AR content } \\
\text { during class. }\end{array}$ & $2.67 \pm 0.92$ & $2.35 \pm 1.01$ & 2.33 & .021 \\
\hline $\begin{array}{l}\text { 4. When AR content is used, children are likely to be confused because } \\
\text { it is difficult to distinguish the virtual world from the real world. }\end{array}$ & $2.95 \pm 0.93$ & $2.74 \pm 1.20$ & 1.44 & .151 \\
\hline $\begin{array}{l}\text { 5. There are concerns that the use of AR will further entrap children in } \\
\text { their own world. }\end{array}$ & $3.08 \pm 1.06$ & $2.83 \pm 1.20$ & 1.62 & .107 \\
\hline $\begin{array}{l}\text { 6. With a lot of AR, it is likely that children will have fewer } \\
\text { opportunities to talk or interact with people. }\end{array}$ & $3.26 \pm 1.02$ & $2.98 \pm 1.22$ & 1.83 & .069 \\
\hline
\end{tabular}

$\mathrm{AR}$, augmented reality.

asthma, peers, parents, and teachers averaged at least 7 out of 10 points or higher in all groups, indicating a substantial need for asthma education. In particular, parents showed the highest demand for asthma education related to children with asthma for peers, parents, and teachers. Children spend much of their time at school, under the supervision of teachers in classrooms [4]. School age is a period when children spend much of their time at school and outside of the home, and the expectation that teachers or peers can provide help in the event of an emergency likely has an effect on children with asthma $[4,20]$. Previous studies, however, have shown that many parents do not trust schools to properly manage their children's asthma. Parents who are more satisfied with their child's asth- ma management at school tend to communicate well with teachers about their child's condition [7]. It is believed that parents want more support for their children from teachers and peers as a result of asthma education, as children with asthma spend much of their time at school. Previous studies have found that children with asthma have a higher degree of asthma self-management ability if they receive adequate support for their disease from teachers, school nurses, and peers $[7,21$, 22]. In addition, previous studies have shown that peers play a crucial role in supporting children's asthma management at school [7,23-25]. Therefore, it is necessary to enhance the self-management ability of children with asthma by providing education to peers and teachers about childhood asthma. 
The high demand for education on the parents themselves seems to come from a belief that they have insufficient knowledge about asthma. Furthermore, this study showed that parents expressed the highest needs for education related to the asthma primary and asthma medication domains. In previous studies, parents of children with asthma tended to be aware of their children's worsening asthma symptoms, but the cause was not always clear. They also had difficulty distinguishing between dyspnea and asthma symptoms when their children were physically active [3]. Health professionals have also found that the acute exacerbation of symptoms tended to occur after parents of children with asthma stopped using preventative inhalers because they thought their children were healthy and did not understand the preventive role of the medication [3]. Although the parents in this study did not have any allergic diseases, including asthma, allergic diseases can develop in anyone's children. Therefore, educating the parents of children with asthma will lead to improvements in the asthma symptoms of their children and other children.

The need for education related to children with asthma was the highest among teachers. This is likely related to our finding that 'coping with asthma and medical expectations' was the domain for which teachers required the most education. In most schools, there is a shortage of healthcare professionals on the teaching staff. As a result, teachers are usually primarily responsible for caring for and supervising children with asthma if they have an acute asthma attack [8]. Therefore, if children with asthma are aware of their symptoms and self-manage them, it will significantly reduce the burden on teachers.

In addition, the most-needed educational item related to school-age children with asthma among peers, parents, and teachers was 'how to deal with asthma attacks.' Asthma attacks are a life-threatening situation for children. A child may not remember how to administer medication during an asthma attack, or they may not be able to administer medication independently without assistance. In such cases, the teacher should help the child inhale asthma medication [26,27]. However, previous studies have found that teachers lacked an adequate understanding of asthma medication and asthma attacks, which jeopardizes the health and well-being of children with asthma. Therefore, children tend to be more likely to ask for help only when they know how to cope with asthma attacks themselves, and they can manage their condition well when they are confident that they can cope on their own.

Searle et al. found that most parents of children with asthma or allergic conditions were worried about a possible anaphylactic reaction at school or during physical activities outside of school [3]. They also found that only a tiny percentage of respondents were confident that their school could respond properly to such emergencies. In addition, previous studies have found that children with asthma and their parents, in general, were familiar with asthma triggers and that symptoms are potentially controllable with appropriate treatment. Children and parents with asthma could use terms such as 'wheezy' and 'breathless' to describe how to recognize the onset of asthma symptoms [3]. However, in this study, the peers and teachers of children with asthma, as well as the parents of children without asthma, answered that terms such as 'shortness of breath' and 'wheezing' were unfamiliar to them. Therefore, it is necessary to provide education on the symptoms that appear when asthma symptoms are exacerbated. Teachers and peers can be the first to help children with asthma when asthma attacks occur at school.

Another one of the most-needed educational items for children with asthma and their peers, parents, and teachers was 'appropriate exercises and an appropriate amount of exercise.' School age is a period of high physical activity, and physical education is important since it can improve ties with peers through exercise. Previous research found that one of the barriers to the treatment of asthma in schools was that students felt different from their peers due to their asthma [7]. A lack of knowledge about asthma may also lead to social isolation at school since children with asthma may be excluded from social and sporting activities, as reported by all of the evaluated groups. Some students described feelings of alienation from their peers during physical activities in which they were not fully engaged and expressed a desire to consider safer, more inclusive activities for children with asthma [5,7]. Physical activity is one of the essential components of asthma management in children. Exercise in children with asthma has been shown to reduce the severity of asthma symptoms and improve cardiorespiratory health $[5,28]$. In addition, a lack of physical activity in children with asthma can lead to obesity, which in turn can make asthma worse [29]. Therefore, by educating parents and teachers on appropriate physical activity for children with asthma and educating children with asthma and their peers on proper physical activity, children with asthma can feel included in activities and develop a more positive relationship with their peers.

No studies have directly examined the expectations of incorporating AR in asthma education. However, in previous studies, both parents and teachers had a positive perception of an AR program $[19,30]$. The results of this study showed that the expectations of teachers and parents concerning the incorporation of AR in asthma education were found to be generally higher for positive expectations than negative concerns. In this study, reflections on parents and teachers also led to higher positive expectations for the incorporation of AR in educational programs. 
Previous research has shown that AR positively impacts students' educational experience, increases confidence, increases engagement and interest levels, provides self-learning opportunities, enhances collaborative learning, increases satisfaction, and increases student motivation [12,13]. In this study, both teachers and parents tended to agree with the items 'it seems that children can get an opportunity to broaden their experiences through the medium of AR,' 'if a child's area or family appears in the AR content, the children will believe they have a friendly relationship with them, which may stimulate interest and motivation,' and 'I want children to have the opportunity to experience it when they hear the news that a new AR program is out.' [12,13]. Both teachers and parents had high expectations for a virtual world coexisting with the real world and interacting with $A R$, believing that a program incorporating AR would attract students' attention and be an exciting tool and educational aid.

This study was conducted only among elementary school students, parents, and teachers in 5 cities and provinces in South Korea, and the study results are thus not easily generalizable. In addition, this study is limited since it was not possible to confirm and measure in more detail the precise educational needs of children with asthma and their peers, parents, and teachers. Therefore, in future research, it is necessary to confirm the precise needs of each group using small group interviews. In addition, the study population should be expanded to younger children with asthma. This study is still significant since it is the first to examine the educational needs concerning asthma of four groups (school-age children with asthma, peers, parents, and teachers) in South Korea. It is also the first study to examine the expectations of parents and teachers concerning the implementation of AR programs for asthma education.

\section{CONCLUSION}

This study aimed to investigate the educational needs for asthma education programs targeted to school-age children, parents, and teachers and examine parents' and teachers' expectations for the incorporation of AR in asthma education. In this study, children with asthma and their peers, parents, and teachers all showed a substantial need for education related to asthma. The items with the highest need for education were 'how to deal with an asthma attack,' 'appropriate exercises and the appropriate amount of exercise,' 'what is harmful/ helpful in case of asthma,' and 'how to take preventive measures.' Therefore, the content of asthma education programs should be designed to address these points in particular.

Both parents and teachers had positive expectations for the incorporation of AR in asthma education programs positive expectations. In the context of the coronavirus disease 2019 (COVID-19) pandemic, various education programs that use AR have been introduced when in-person learning was impossible. By developing an asthma education program that uses an AR program to simulate asthma management, children with asthma will likely learn to independently and effectively manage their condition. In addition, parents, teachers, and peers can participate in an AR program together with children with asthma to improve their understanding of asthma and improve children with asthma's symptoms and quality of life through social support.

\section{ORCID}

Yunsoo Kim https://orcid.org/0000-0002-1788-563X

Hyojin Ju https://orcid.org/0000-0002-1164-3621

\section{Authors' contribution}

Conceptualization: Yunsoo Kim; Data collection: all authors; Formal analysis: Yunsoo Kim; Writing-original draft, Writingreview and editing: all authors; Final approval of published version: all authors.

\section{Conflict of interest}

No existing or potential conflict of interest relevant to this article was reported.

\section{Funding}

This study was supported by a National Research Foundation of Korea (NRF) grant funded by the Korean government (No. NRF-2019R1G1A1010610).

\section{Data availability}

Please contact the corresponding author for data availability.

\section{Acknowledgements}

None.

\section{REFERENCES}

1. Ish P, Malhotra N, Gupta N. GINA 2020: What's new and why? Journal of Asthma. 2020;58(10):1273-1277. https://doi.org/10.1080/02770903.2020.1788076

2. National Health Insurance Service. "Allergic rhinitis" has the highest number of patients under the age of 10 South Korea 2020 
[Internet]. Wonju: National Health Insurance Service; 2020 [cited 2021 August 02]. Available from:

https://www.nhis.or.kr/nhis/together/wbhaea01600m01.do? mode $=$ view $\&$ articleNo $=136900$

3. Searle A, Jago R, Henderson J, Turner KM. Children's, parents' and health professionals' views on the management of childhood asthma: A qualitative study. NPJ Primary Care Respiratory Medicine. 2017;27(1):53. https://doi.org/10.1038/s41533-017-0053-7

4. Lucas T, Anderson MA, Hill PD. What level of knowledge do elementary school teachers possess concerning the care of children with asthma? A pilot study. Journal of Pediatric Nursing. 2012;27 (5):523-527. https://doi.org/10.1016/j.pedn.2011.07.004

5. Kornblit A, Cain A, Bauman LJ, Brown NM, Reznik M. Parental perspectives of barriers to physical activity in urban schoolchildren with asthma. Academic Pediatrics. 2018;18(3):310-316. https://doi.org/10.1016/j.acap.2017.12.011

6. Glazebrook C, McPherson AC, Macdonald IA, Swift JA, Ramsay C, Newbould R, et al. Asthma as a barrier to children's physical activity: Implications for body mass index and mental health. Pediatrics. 2006;118(6):2443-2449. https://doi.org/10.1542/peds.2006-1846

7. Naman J, Press VG, Vaughn D, Hull A, Erwin K, Volerman A. Student perspectives on asthma management in schools: A mixedmethods study examining experiences, facilitators, and barriers to care. Journal of Asthma. 2019;56(12):1294-1305.

https://doi.org/10.1080/02770903.2018.1534968

8. Kew KM, Carr R, Donovan T, Gordon M. Asthma education for school staff. Cochrane Database of Systematic Reviews. 2017;4(4): CD012255. https://doi.org/10.1002/14651858.CD012255.pub2

9. Marilyn J H, David W. Wong's nursing care of infants and children. 9th ed. Kidlington: Elsevier Health Sciences; 2014.

10. Nabavi RT. Bandura's social learning theory and social cognitive learning theory. Theory of Developmental Psychology. 2012:1-23.

11. Qiao X, Ren P, Dustdar S, Liu L, Ma H, Chen J. Web AR: A promising future for mobile augmented reality-State of the art, challenges, and insights. Proceedings of the IEEE. 2019;107(4):651-666. https://doi.org/10.1109/jproc.2019.2895105

12. Tait AR, Connally L, Doshi A, Johnson A, Skrzpek A, Grimes M, et al. Development and evaluation of an augmented reality education program for pediatric research. Journal of Clinical and Translational Research. 2020;5(3):96-101.

https://doi.org/10.18053/jctres.05.202003.002

13. Sheth A, Jaimini U, Thirunarayan K, Banerjee T. Augmented personalized health: How smart data with IoTs and AI is about to change healthcare. 2017 IEEE 3rd international forum on research and technologies for society and industry (RTSI); 2017 September 11-13. Medena: IEEE; 2017. p. 1-6. https://doi.org/10.1109/rtsi.2017.8065963

14. Faul F, Erdfelder E, Lang AG, Buchner A. G* Power 3: A flexible statistical power analysis program for the social, behavioral, and biomedical sciences. Behavior Research Methods. 2007;39(2): 175-191. https://doi.org/10.3758/bf03193146

15. Archibald MM, Scott SD. The information needs of North American parents of children with asthma: A state-of-the-science review of the literature. Journal of Pediatric Health Care. 2014;28(1):5-13. e2. https://doi.org/10.1016/j.pedhc.2012.07.003

16. Lenney W, Bush A, Fitzgerald DA, Fletcher M, Ostrem A, Pedersen $S$, et al. Improving the global diagnosis and management of asthma in children. Thorax. 2018;73(7):662-669.

https://doi.org/10.1136/thoraxjnl-2018-211626

17. Ong KY. What's new in the Global Initiative for Asthma 2018 report and beyond. Allergo Journal International. 2019;28(2):63-72. https://doi.org/10.1007/s40629-018-0079-6

18. Archibald MM, Caine V, Ali S, Hartling L, Scott SD. What is left unsaid: An interpretive description of the information needs of parents of children with asthma. Research in Nursing and Health. 2015;38(1):19-28. https://doi.org/10.1002/nur.21635

19. Park KO, Baek J, Seo S, Lee Y. Investigating preservice special education teachers' perceptions on applying augmented reality (AR) to special education and its presence factors affecting AR. Journal of Special Education: Theory and Practice. 2016;17(1):189-207.

20. Adeyeye OO, Kuyinu YA, Ozoh OB. Assessment of the knowledge of teachers about asthma and the availability of facilities for asthma care in public secondary schools in Lagos, Nigeria. African Journal of Thoracic and Critical Care Medicine. 2018;24(2):76-81. https://doi.org/10.7196/sarj.2018.v24i2.192

21. Munzenberger P, Secord E, Thomas R. Relationship between patient, caregiver, and asthma characteristics, responsibility for management, and indicators of asthma control within an urban clinic. Journal of Asthma. 2010;47(1):41-45. https://doi.org/10.3109/02770900903395226

22. Polloni L, Baldi I, Lazzarotto F, Bonaguro R, Toniolo A, Celegato N, et al. School personnel's self-efficacy in managing food allergy and anaphylaxis. Pediatric Allergy and Immunology. 2016;27(4):356-360. https://doi.org/10.1111/pai.12550

23. Rhee H, McQuillan B, Chen DG, Atis S. Perceptions about interpersonal relationships and school environment among middle school students with asthma. Journal of Asthma. 2017;54(9):905910. https://doi.org/10.1080/02770903.2016.1277540

24. Kew KM, Carr R, Crossingham I. Lay-led and peer support interventions for adolescents with asthma. Cochrane Database of Systematic Reviews. 2017;4(4):CD012331. https://doi.org/10.1002/14651858.CD012331.pub2

25. Johnson SB, Spin P, Connolly F, Stein M, Cheng TL, Connor K. Asthma and attendance in urban schools. Preventing Chronic Disease. 2019;16:E148. https://doi.org/10.5888/pcd16.190074

26. Bell HM, McElnay JC, Hughes CM, Gleadhill I. Primary schoolteachers' knowledge of asthma: The impact of pharmacist intervention. Journal of Asthma. 2000;37(7):545-555. https://doi.org/10.3109/02770900009090809 
27. Henry RL, Gibson PG, Vimpani GV, Francis JL, Hazell J. Randomized controlled trial of a teacher-led asthma education program. Pediatric Pulmonology. 2004;38(6):434-442.

https://doi.org/10.1002/ppul.20095

28. Eichenberger PA, Diener SN, Kofmehl R, Spengler CM. Effects of exercise training on airway hyperreactivity in asthma: A systematic review and meta-analysis. Sports Medicine. 2013;43(11):1157-1170. https://doi.org/10.1007/s40279-013-0077-2
29. Dooley AA, Pillai DK. Paediatric obesity-related asthma: Disease burden and effects on pulmonary physiology. Paediatric Respiratory Reviews. 2021;37:15-17.

https://doi.org/10.1016/j.prrv.2020.04.002

30. Cheng KH. Parents' user experiences of augmented reality book reading: Perceptions, expectations, and intentions. Educational Technology Research and Development. 2019;67(2):303-315.

https://doi.org/10.1007/s11423-018-9611-0 